\title{
Seismicity of the South Far East of Russia in 2018
}

\author{
Dmitry A. Safonov*1,2 \\ Tatyana A. Fokina ${ }^{1}$ \\ Natalya S. Kovalenko ${ }^{1}$
}

\author{
${ }^{1}$ Sakhalin Branch of the Federal Research Center "United Geophysical \\ Service of the Russian Academy of Sciences", Yuzhno-Sakhalinsk, Russia \\ ${ }^{2}$ Institute of Marine Geology and Geophysics, FEB RAS, \\ Yuzhno-Sakhalinsk, Russia \\ *E-mail: d.safonov@imgg.ru
}

\section{Abstract Реферат PDF Rus}

The article contains a description of the seismicity of the Amur region, Primorye, KurilOkhotsk and Sakhalin regions in 2018. The paper shows the modern registration capabilities of the Sakhalin branch of the Federal Research Center United Geophysical Service RAS (SF FRC UGS RAS), Yuzhno-Sakhalinsk. We describe the strongest earthquakes most felt by the inhabitants of the region. The focal mechanisms of strong events are presented, and assumptions about the nature of their source are made. It is shown that seismicity in 2018 for the territory of the Sakhalin branch of the FRC UGS RAS was relatively calm, although somewhat more remarkable in comparison with the last decade. It differs only in the area of the northern Kuril Islands, where seismic activity in 2018 was higher than the long-term average level.

\section{Keywords}

earthquakes, seismicity, seismic activity, earthquake focal mechanism, Amur region, Primorye, Sakhalin, Kuril-Okhotsk region

For citation: Safonov D.A., Fokina T.A., Kovalenko N.S. Seismicity of the South Far East of Russia in 2018. Geosystems of Transition Zones. 2019, vol. 3, no. 4, pp. 364-376. (In Russian) https://doi.org/10.30730/25418912.2019.3.4.364-376

Для цитирования: Сафонов Д.А., Фокина Т.А., Коваленко Н.С. Сейсмичность юга Дальнего Востока России в 2018 году. Геосистемы переходных зон. 2019. Т. 3, № 4. С. 364-376. https://doi.org/10.30730/25418912.2019.3.4.364-376

\section{References}

1. Габсатарова И.П. Границы сейсмоактивных регионов с 2004 г. // Землетрясения России в 2004 году. Обнинск: ГС РАН, 2007. С. 139.

2. Злобин Т.К., Поплавская Л.Н., Левин Б.В., Сафонов Д.А., Полец А.Ю., Рудик М.И. Вариации поля упругих напряжений и основные сеймодислокации в очаговой зоне Шикотанского землетрясения 04(05) октября 1994 г. // Доклады Академии наук. 2008. Т. 419, № 6. С. 820-823.

3. Медведев С.В., Шпонхойер В., Карник В. Шкала сейсмической интенсивности MSK-64. М.: МГК АН ССCР, 1965. $11 \mathrm{c}$

4. Раутиан Т.Г. Об определении энергии землетрясений на расстоянии до 3000 км // Экспериментальная сейсмика. М.: Наука, 1964. С. 88-93. (Труды ИФЗ АН СССР; № 32(199))

5. Ризниченко Ю.В. Метод суммирования землетрясений для изучения сейсмической активности // Изв. АН СССР. Сер. геофиз. 1964. № 7. С. 969-977.

6. Рогожин Е.А., Левина В.И. Симуширские землетрясения 15 ноября 2006 г. (I) и 13 января 2007 г. (II) c $\mathrm{Mw}=8.3$ и Мw=8.1 (Средние Курилы) // Землетрясения Северной Евразии, 2007 г. Обнинск: ГС PAH, 2013. C. 326-338

7. Сафонов Д.А. Современное поле тектонических напряжений территории Приамурья // Геодинамика и тектонофизика. 2018. Т. 9, № 3. С. 1025-1037. doi:10.5800/GT-2018-9-3-0382

8. Сафонов Д.А. Пространственное распределение тектонических напряжений в южной глубокой части Курило-Камчатской зоны субдукции = Safonov D.A. Spatial distribution of tectonic stress in the southern 
deep part of the Kuril-Kamchatka subduction zone // Геосистемь переходных зон = Geosystems of Transition Zones. 2019. T. 3, № 2. C. 175-188. doi:10.30730/2541-8912.2019.3.2.175-188

9. Сафонов Д.А., Коновалов А.В. Использование программы ISOLA для определения тензора сейсмического момента землетрясений Курило-Охотского и Сахалинского регионов // Тихоокеанская геология. 2017. Т. 36, № 3. С. 102-112.

10. Сейсмическое районирование территории СССР. Методические основы и региональное описание карты 1978 г. / отв. ред. В.И. Бунэ, Г.П. Горшков. М.: Наука, 1980. 308 с.

11. Семенова Е.П., Костылев Д.В., Михайлов В.И., Паршина И.А., Ферчева В.Н. Оценка сейсмичности южного Сахалина по методике СОУС'09 = Semenova E.P., Kostylev D.V, Mikhailov V.I., Parshina I.A., Fercheva V.N. Evaluation seismicity in Southern Sakhalin with the use of the method SOUS'09 // Геосистемы переходных зон = Geosystems of Transition Zones. 2018. Т. 2, № 3. С. 191-195. doi:10.30730/2541-8912.2018.2.3.191-195.

12. Соловьев С.Л., Соловьева О.Н. Соотношение между энергетическим классом и магнитудой Курильских землетрясений // Физика земли. 1967. № 2. С. 13-22.

13. Фокина Т.А., Сафонов Д.А., Дорошкевич Е.Н., Костылев Д.В. Курило-Охотский регион // Землетрясения Северной Евразии, 2011 год. Обнинск: ФИЦ ЕГС РАН, 2017. С. 170-180.

14. Фокина Т.А., Коваленко Н.С., Костылев Д.В., Левин Ю.Н., Лихачева О.Н., Михайлов В.И. Приамурье и Приморье, Сахалин и Курило-Охотский регион // Землетрясения России в 2016 году. Обнинск: ФИЦ ЕГС РАН, 2018. С. 45-53.

15. Чебров В.Н., Кугаенко Ю.А., Викулина С.А., Кравченко Н.М., Матвеенко Е.А., Митюшкина С.В., Раевская А.А., Салтыков В.А., Чебров Д.В., Ландер А.В. Глубокое Охотоморское землетрясение 24.05. 2013 г. с магнитудой $\mathrm{Mw}=8.3$ - сильнейшее сейсмическое событие у берегов Камчатки за период детальных сейсмологических наблюдений // Вестник КРАУНЦ. Науки о Земле. 2013. № 1, вып. 21. С. 17-24.

16. Benioff H. Earthquakes and rock creep // Bulletin of the Seismological Society of America. 1951. Vol. 41, N 1. P. 31-62.

17. Christova C.V. Spatial distribution of the contemporary stress field in the Kurile Wadati-Benioff zone by inversion of earthquake focal mechanisms // J. of Geodynamics. 2015. T. 83. P. 1-17. https://doi.org/10.1016/j.jog.2014.11.001

18. NIED - National Research Institute for Earth Science and Disaster Prevention, Japan. URL: http://www.fnet.bosai.go.jp

19. Sokos E., Zahradník J. Evaluating Centroid-Moment-Tensor Uncertainty in the New Version of ISOLA Software // Seismological Research Letters. 2013. Vol. 84. P. 656-665. https://doi.org/10.1785/0220130002 